\title{
Regional and monthly and clear-sky aerosol direct radiative effect (and forcing) derived from the GlobAEROSOL-AATSR satellite aerosol product
}

\author{
G. E. Thomas ${ }^{1}$, N. Chalmers ${ }^{2}$, B. Harris ${ }^{2}$, R. G. Grainger ${ }^{1}$, and E. J. Highwood ${ }^{2}$ \\ ${ }^{1}$ Atmospheric, Oceanic and Planetary Physics, University of Oxford, Oxford, UK \\ ${ }^{2}$ Department of Meteorology, University of Reading, Reading, UK \\ Correspondence to: G. E. Thomas (gthomas@atm.ox.ac.uk)
}

Received: 4 June 2012 - Published in Atmos. Chem. Phys. Discuss.: 27 July 2012

Revised: 22 December 2012 - Accepted: 3 January 2013 - Published: 15 January 2013

\begin{abstract}
Using the GlobAEROSOL-AATSR dataset, estimates of the instantaneous, clear-sky, direct aerosol radiative effect and radiative forcing have been produced for the year 2006. Aerosol Robotic Network sun-photometer measurements have been used to characterise the random and systematic error in the GlobAEROSOL product for 22 regions covering the globe. Representative aerosol properties for each region were derived from the results of a wide range of literature sources and, along with the de-biased GlobAEROSOL AODs, were used to drive an offline version of the Met Office unified model radiation scheme. In addition to the mean AOD, best-estimate run of the radiation scheme, a range of additional calculations were done to propagate uncertainty estimates in the AOD, optical properties, surface albedo and errors due to the temporal and spatial averaging of the AOD fields. This analysis produced monthly, regional estimates of the clear-sky aerosol radiative effect and its uncertainty, which were combined to produce annual, global mean values of $(-6.7 \pm 3.9) \mathrm{W} \mathrm{m}^{-2}$ at the top of atmosphere (TOA) and $(-12 \pm 6) \mathrm{W} \mathrm{m}^{-2}$ at the surface. These results were then used to give estimates of regional, clear-sky aerosol direct radiative forcing, using modelled pre-industrial AOD fields for the year 1750 calculated for the AEROCOM PRE experiment. However, as it was not possible to quantify the uncertainty in the pre-industrial aerosol loading, these figures can only be taken as indicative and their uncertainties as lower bounds on the likely errors. Although the uncertainty on aerosol radiative effect presented here is considerably larger than most previous estimates, the explicit inclusion of the major sources of error in the calculations suggest
\end{abstract}

that they are closer to the true constraint on this figure from similar methodologies, and point to the need for more, improved estimates of both global aerosol loading and aerosol optical properties.

\section{Introduction}

Atmospheric aerosol has been held responsible for considerable uncertainty in radiative forcing estimates and the resulting predictions of future climate (Forster et al., 2007). The diversity of sources and composition of aerosol produces substantial spatial and temporal variability of amount, characteristics and impact on the Earth's energy budget. However it is these regional variations that are likely to play a large role in defining regional climate impacts. For example the current estimate of the global mean radiative forcing due to all anthropogenic aerosols given the Intergovernmental Panel on Climate Change is $(-0.5 \pm 0.4) \mathrm{W} \mathrm{m}^{-2}$ but the regional forcing over areas of high emission can be up to 10 times larger (Forster et al., 2007). Although it is not possible to directly map regional radiative forcings onto regional climate response, because the spatial dependency of feedbacks is also important (e.g. Boer and Yu, 2003), it is probable that such large variations in forcing would lead to strong regional differences in response. The spatial pattern of radiative forcing is also responsible for some of the largest differences in forcing between different models. Reasons for this include the speciation of the aerosols, their prescribed or predicted optical properties and their interactions with clouds. In 
addition, Forster et al. (2007) showed a discrepancy between model-derived estimates and measurement-derived estimates of radiative forcing, with estimates derived from satellite estimates showing a more negative direct aerosol radiative forcing. Myhre (2009) demonstrated that much of this discrepancy resulted from the choice of non-evolving optical properties in the modelling study. If models assumed that the optical properties changed over time (something not captured by the satellite data) then the estimates from the different methodologies were brought closer together. Myhre (2009) also suggested that radiative forcing estimates of the direct effect must at least partly rely on the use of models.

The two primary quantities calculated in this work are the instantaneous, clear-sky (i.e. only considering cloud-free conditions), direct aerosol radiative effect (ARE) and radiative forcing. A wide variety of global estimates of these quantities exists in the literature, for different modelling and measurement approaches. Bellouin et al. (2005) used the Moderate Resolution Imaging Spectroradiometer (MODIS) Collection 4 aerosol product to estimate global direct clearsky aerosol forcing at $-1.9 \mathrm{~W} \mathrm{~m}^{-2}$ at the TOA. Subsequent work using Collection 5 data and constraints from the HadGEM2-A model (Bellouin et al., 2008) has produced a revised estimate of $-1.3 \mathrm{~W} \mathrm{~m}^{-2}$ from MODIS. The HadGEM2-A estimate of the same quantity was given by Bellouin et al. (2008) as $-0.63 \mathrm{~W} \mathrm{~m}^{-2}$, with most of the discrepancy from the MODIS derived estimate resulting from assumptions made in determining the anthropogenic aerosol component of MODIS AOD over land. Results from the AEROCOM model intercomparison project (Schulz et al., 2006) produced a clear-sky aerosol radiative forcing estimate of $(-0.66 \pm 0.24) \mathrm{W} \mathrm{m}^{-2}$ from a sample of 12 models.

Remer and Kaufman (2006) estimated the TOA ARE from MODIS measurements over the ocean to be between $(-5.0 \pm 0.6)$ and $(-5.5 \pm 0.6) \mathrm{W} \mathrm{m}^{-2}$, depending on the assumed aerosol properties used in the retrieval. Yu et al. (2006) presents a review of the then available estimates of TOA ARE from a range of instruments and models, with over-ocean estimates ranging from -2.7 to $-11 \mathrm{~W} \mathrm{~m}^{-2}$, but produce a best estimate of $(-5.5 \pm 0.2) \mathrm{W} \mathrm{m}^{-2}$, with a corresponding over-land estimate of $(-4.9 \pm 0.7) \mathrm{W} \mathrm{m}^{-2}$. Zhao et al. (2008) provide an estimate of $(-5.0 \pm 1.7) \mathrm{W} \mathrm{m}^{-2}$ for the global TOA ARE, as well as a breakdown of ARE by aerosol component, using a combination of Clouds and Earth's Radiant Energy System (CERES) measurements and the Goddard Chemistry Aerosol Radiation and Transport (GOCART) model.

Two circumstances motivate the research presented in this paper. Firstly there is much current research activity concerning the derivation of more quantitative satellite derived estimates of both aerosol amount (measured by aerosol optical depth, AOD), aerosol type (e.g. continental, maritime) and aerosol properties such as effective radius. In this study we use a newly available dataset from the European Space Agency (ESA) Data User Element project
GlobAEROSOL using the Advanced Along-Track Scanning Radiometer (AATSR) satellite instrument. It is important to quantify the direct radiative forcing implied using the properties described within this dataset and to place these in the context of other estimates. Secondly, there remains a considerable number of reasons why the uncertainty in aerosol direct forcing estimates is large (Kahn, 2012). It is therefore necessary to provide quantitative estimates of the sources of uncertainty associated with both the data sources and the calculation methodology and tools.

\section{Tools}

To calculate radiative forcing and quantify the impact of varying sources of uncertainty, we need data including aerosol amount (e.g. optical depth) in both the present day and the pre-industrial era, aerosol vertical profile, aerosol scattering properties (themselves a function of size and composition), and a radiative transfer code.

\subsection{Present day aerosol optical depth}

The source of the satellite measurements of AOD used in this work is the GlobAEROSOL-AATSR dataset. GlobAEROSOL produced a set of satellite based aerosol products from a range of European satellite sensors, namely: the second Along Track Scanning Radiometer (ATSR-2) on the ERS-2 satellite; AATSR and the MEdium Resolution Imaging Spectrometer (MERIS) on ENVISAT; and the Spinning Enhanced Visible-InfraRed Imager (SEVIRI) on the second generation Meteosat geostationary satellites. Of the four instruments included in GlobAEROSOL, only data from AATSR were used in this study, as ATSR-2 data were not available for 2006, SEVIRI does not offer global coverage and there are known quality issues with the GlobAEROSOL MERIS product.

GlobAEROSOL products for all instruments were produced on a common sinusoidal grid with a nominal resolution of $10 \mathrm{~km}$. Data are available in orbit-by-orbit (level 2) files, as well as daily and monthly averages (level 3). A full description of the algorithm as applied to AATSR in GlobAEROSOL is given by Thomas et al. (2009a).

\subsubsection{Retrieval description}

The GlobAEROSOL-AATSR product was produced using the Oxford-RAL Aerosol and Cloud (ORAC) retrieval algorithm (as were the ATSR-2 and SEVIRI GlobAEROSOL products, while the MERIS product was based on the ESA operational atmospheric correction retrieval). ORAC is an optimal estimation retrieval scheme which can be applied to the retrieval of either aerosol or cloud properties from a range of visible-infrared satellite imaging instruments. As applied to AATSR in GlobAEROSOL, the ORAC algorithm retrieves AOD at $550 \mathrm{~nm}$, aerosol effective radius and 
the bihemispheric surface reflectance at the four short-wave AATSR channels (centred at 550, 670, 870 and $1600 \mathrm{~nm}$ ). The GlobAEROSOL products also include the AOD at $870 \mathrm{~nm}$, which is determined from the assumed aerosol properties, and the retrieved $550 \mathrm{~nm}$ AOD and effective radius.

Retrievals are performed using five different aerosol "classes" and the retrieval fit-quality, in addition to strong a priori constraints, is used to select the most likely class for each pixel. The five aerosol classes used in GlobAEROSOL are continental-clean, maritime-clean, desert-dust and urban, from the Optical Properties of Aerosol and Cloud database (Hess et al., 1998); and biomass-burning derived from AERONET measurements of South American Cerrado fires (Dubovik et al., 2002). Each of these aerosol classes is modelled as an external mixture of between two and five different components, with each component being described by a different log-normal size distribution and refractive index. Although only five distinct aerosol classes were used in GlobAEROSOL, the retrieval of aerosol effective radius is achieved in ORAC by varying the mixing ratios of the components within each class, providing a continuous variation of aerosol properties within each of the five broad classes.

In general the accuracy of satellite measurements of aerosol is limited by four factors:

1. Decoupling the atmospheric signal (including that from aerosol) from the surface signal in the top-ofatmosphere (TOA) radiance measured by the satellite.

2. The removal of all measurements that are affected by cloud, while not removing areas of heavy aerosol loading.

3. Assumptions which must be made about the microphysical properties of the aerosol (complex refractive index, size distribution, height distribution) that affect the TOA signal, but about which the TOA measurements do not provide enough information to unambiguously determine.

4. Instrumental uncertainty, resulting from calibration errors and measurement noise for example.

The ATSR instruments provide near simultaneous measurements of the same region at different viewing geometries. The instrument first makes a measurement at a zenith angle of approximately $55^{\circ}$ along the orbit track of the satellite, followed by a second measurement ( $90 \mathrm{~s}$ later) centred on the nadir direction. Under the assumption that the composition of the atmosphere is consistent along these two viewing directions, and with knowledge of the bidirectional reflectance distribution function (BRDF) of the underlying surface, these so-called dual-view measurements offer an effective way of separating the surface and atmospheric signatures. In ORAC, prior knowledge of the BRDF is provided by the MODIS MCD43B1 land surface BRDF product over land surfaces, and by an ocean surface reflectance model over the sea. With this constraint on the directional dependence of the surface reflectance, the algorithm is able to retrieve the surface albedo in addition to the AOD and effective radius ${ }^{1}$.

Cloud clearing of AATSR for GlobAEROSOL was based on the operational cloud mask used for AATSR surface temperature retrievals (the primary mission of the ATSR instruments). In addition to this mask, additional cloud screening was done post-retrieval, with pixels which showed elevated AOD or effective radius and/or a high degree of AOD heterogeneity being masked as poor quality.

\subsubsection{Regional and temporal AOD characterisation}

For this work GlobAEROSOL-AATSR products were used to characterise the AOD across the globe on a regional basis for the year 2006 (the AEROCOM reference year). In order to do this, AOD data were composited both temporally and spatially from the orbit-by-orbit level 2 data - the GlobAEROSOL level 3 composite products were not used in this work. The regions used in this analysis are shown in Fig. 1 and were chosen to have either broadly consistent aerosol properties, or to be regions across which aerosol properties are too spatially variable to hope to accurately characterise within the scope of this study (for example the AL08 region).

As ORAC is an optimal estimation retrieval scheme, full error propagation is an integral part of the system and uncertainty estimates are provided for each retrieved quantity. These uncertainties map the measurement noise and estimates of errors introduced by forward model approximations and assumptions onto the retrieved parameters and can thus be considered as a measurement of the precision of a given retrieval (i.e. how well the measurements constrain the retrieved properties), as opposed to the accuracy of the retrieval, which can only be estimated by comparison against ground-truth data.

These uncertainties were used in calculating monthly weighted mean AOD values for each of the 22 regions shown in Fig. 1. Additionally, $1 \times 1^{\circ}$ daily averages were produced for April 2006 in order to characterise uncertainties introduced by the regional and monthly averaging.

\subsubsection{Bias correction and uncertainty characterisation}

Validation against in situ or ground-truth measurements is an important aspect of the development of any remotely sensed dataset, and is particularly important for an underconstrained problem such as satellite aerosol retrieval. In the case of AOD ground truth measurements are generally provided by sun photometer measurements, and by the Aerosol Robotic Network (AERONET) in particular.

\footnotetext{
${ }^{1}$ The a priori surface reflectance fixes the angular dependence (i.e. the ratio of the reflectance at the two AATSR views), while the magnitude of the surface reflectance is a free retrieval parameter, with a minimum $1 \sigma$ prior constraint of 0.02 .
} 
AERONET provided the basis for the validation of the GlobAEROSOL products at the time of production (Poulsen et al., 2009) and this analysis has been extended in order to provide a regional analysis of the uncertainties and biases in the GlobAEROSOL-AATSR AOD product for each of the 22 regions used in this study. The method used for this analysis was:

- Spatial/temporal matches between the GlobAEROSOL AATSR level 2 data and a subset of AERONET stations - selected on the basis of their representativeness of their surrounding regions (S. Kinne, personal communication, 2006. See Kinne et al. (2003) for an explanation of the methodology used in selecting sites) - were determined.

- Satellite data within a $20 \mathrm{~km}$ radius and AERONET data within $30 \mathrm{~min}$ of the satellite overpasses were averaged to provide representative AOD values for the immediate area of each station for each overpass.

- The difference between these satellite and AERONET estimates of AOD was taken, and a PDF of these differences created for each region.

- Each of these PDFs was examined individually and a representative mean and standard deviation were computed; either through direct calculation using the standard formulae, or by fitting a Gaussian curve to the PDF (whichever provided the most reasonable description of the PDF). The results of this analysis can be found in Table 1.

Due to the limited spatial sampling of the AATSR instrument, which results from its relatively narrow swath width of $512 \mathrm{~km}$, this analysis has been applied to the full GlobAEROSOL time series of mid 2002 through to the end of 2007, rather than solely to the data from 2006 used in this study. This approach assumes that the accuracy of the GlobAEROSOL product is consistent through time. This assumption is reasonable for most regions where aerosol composition and loading have not shown large trends over the five years in question, due to the stability of the AATSR calibration. In the case of a large trend in aerosol loading that results in a change in the accuracy of the GlobAEROSOL result over time, this assumption can be expected to lead to an inappropriate GlobAEROSOL-AERONET bias for 2006 conditions. However, the increased width of the difference PDF that would also result would produce a larger standard deviation, somewhat mitigating this problem with a larger AOD uncertainty.

The use of temporal averaging of AERONET data and spatial averaging of level 2 satellite products when comparing the two is common practice (Ichoku et al., 2002; Thomas et al., 2010). It is an attempt to reduce the sampling differences between the two measurement systems - on the basis that the spatial averaging of a view of $10 \mathrm{~km}^{2}$ satellite pixels

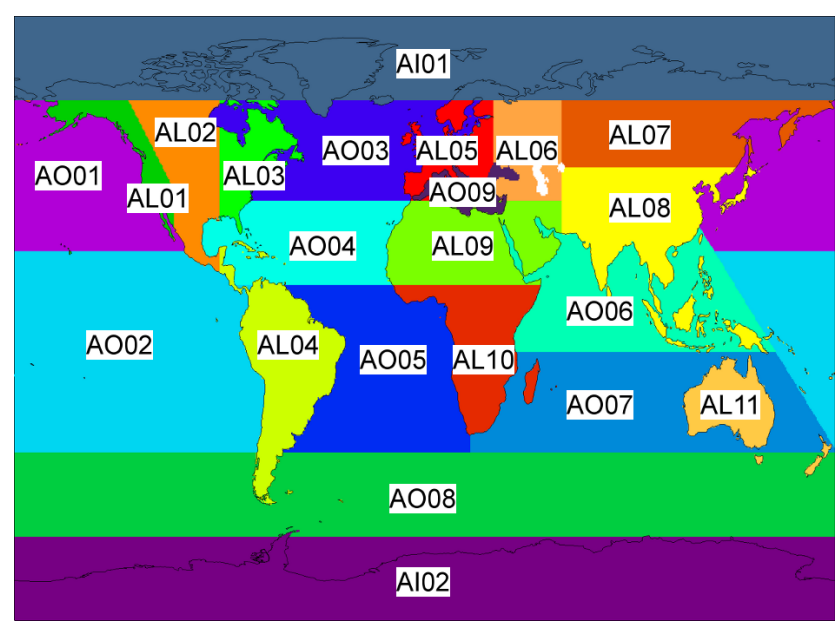

Fig. 1. Map of the 22 regions (11 land, 9 ocean, and 2 ice) over which the radiation calculations are done.

and the temporal averaging of an hour's worth of AERONET data represent values taken over air masses of similar sizes and to increase the number of matches between satellite and AERONET. The latter point is particularly pertinent when using coastal or island based AERONET sites to evaluate satellite AOD products over the oceans, where the spatial averaging of the satellite data can be limited to those pixels which lie over water.

Table 1 shows that, despite the use of over five years of data, the global inhomogeneity of AERONET leads to some regions providing very few or no matches between the two datasets. This is particularly true of the polar regions (AI01 and AI02) and some of the ocean regions (AO05, AO08, $\mathrm{AO} 07$ and AO02). The presence of regions with small numbers of matches (less than $\sim 50$ ) necessitated the use of leastsquares fits of Gaussian curves to some of the error PDFs, to overcome the sensitivity of the mean and standard deviation to outliers. In the case of a (near) complete lack of matches, uncertainty estimates were based on similar regions (for the ocean regions) or the global PDF (for the polar regions).

Overall, Table 1 indicates GlobAEROSOL is in good agreement with AERONET, with the majority of regions showing a bias and standard deviation of less than 0.1 in AOD at both 550 and $870 \mathrm{~nm}$ wavelengths. It should be noted that these results show that the product is comparable, but with greater uncertainties, to other more mature and widely used satellite aerosol products. For example Levy et al. (2010) quote the widely used MODIS Collection 5 land "dark-target" AOD product as having an RMS of 0.12, a Pearson correlation coefficient of $R=0.9$ and an overall uncertainty of $\pm(0.05+0.15 \tau)$, when validated against AERONET. For comparison, globally and over land only, GlobAEROSOL provides an RMS of 0.14 and a correlation of $R=0.7$, with the values over ocean being $\mathrm{RMS}=0.15$ 
Table 1. Regional error analysis of the GlobAEROSOL-AATSR AOD dataset against AERONET. Values for the number of acceptable matches, root-mean-squared difference (RMS) of retrieved AOD, average bias (GlobAEROSOL-AERONET) and standard deviation of the bias $(\sigma)$ are given. Italic values indicate those estimated from similar regions or the global comparison due to a lack of AERONETGlobAEROSOL matches. Note that differences between the number of matchups at 550 and 870 nm are due to AERONET not always providing AOD measurements at all wavelengths.

\begin{tabular}{lrrrr|rrrr}
\hline Region & $550 \mathrm{~nm}$ AOD & & & $870 \mathrm{~nm}$ AOD & & \\
\cline { 2 - 8 } & Matches & RMS & Bias & $\sigma$ & Matches & RMS & Bias & $\sigma$ \\
\hline AO01 & 47 & 0.092 & 0.076 & 0.052 & 47 & 0.079 & 0.064 & 0.047 \\
AO02 & 12 & 0.056 & 0.048 & 0.031 & 12 & 0.048 & 0.042 & 0.025 \\
AO03 & 33 & 0.126 & 0.098 & 0.074 & 33 & 0.101 & 0.080 & 0.063 \\
AO04 & 40 & 0.203 & 0.156 & 0.131 & 40 & 0.210 & 0.160 & 0.140 \\
AO05 & 0 & & 0.156 & 0.131 & 0 & & 0.160 & 0.140 \\
AO06 & 77 & 0.246 & 0.180 & 0.092 & 77 & 0.236 & 0.163 & 0.099 \\
AO07 & 1 & & 0.064 & 0.059 & 0 & & 0.050 & 0.050 \\
AO08 & 0 & & 0.064 & 0.059 & 0 & & 0.050 & 0.050 \\
AO09 & 114 & 0.132 & 0.087 & 0.063 & 114 & 0.100 & 0.060 & 0.053 \\
AL01 & 471 & 0.048 & -0.011 & 0.032 & 453 & 0.034 & -0.003 & 0.034 \\
AL02 & 425 & 0.051 & -0.011 & 0.032 & 424 & 0.039 & -0.003 & 0.034 \\
AL03 & 268 & 0.076 & -0.010 & 0.036 & 268 & 0.058 & 0.015 & 0.056 \\
AL04 & 140 & 0.122 & -0.031 & 0.084 & 140 & 0.082 & -0.023 & 0.050 \\
AL05 & 662 & 0.092 & -0.032 & 0.053 & 662 & 0.063 & -0.016 & 0.032 \\
AL06 & 30 & 0.166 & 0.017 & 0.078 & 30 & 0.129 & 0.008 & 0.019 \\
AL07 & 56 & 0.094 & 0.000 & 0.030 & 56 & 0.070 & 0.008 & 0.022 \\
AL08 & 112 & 0.108 & -0.050 & 0.046 & 112 & 0.083 & -0.035 & 0.035 \\
AL09 & 272 & 0.322 & -0.131 & 0.074 & 272 & 0.340 & -0.122 & 0.029 \\
AL10 & 96 & 0.090 & -0.023 & 0.087 & 96 & 0.063 & 0.012 & 0.062 \\
AL11 & 147 & 0.072 & -0.011 & 0.035 & 135 & 0.047 & -0.001 & 0.025 \\
A101 & 0 & & 0.0 & 0.050 & 0 & & 0.0 & 0.050 \\
AI02 & 0 & & 0.0 & 0.050 & 0 & & 0.0 & 0.050 \\
\hline Globe & 3019 & 0.127 & -0.007 & 0.031 & 2988 & 0.120 & -0.007 & 0.031 \\
\hline & & & & & & & &
\end{tabular}

(due to a systematic bias) and $R=0.9$, respectively (Poulsen et al., 2009).

It is interesting that the largest regional standard deviations and biases (although not RMS difference, which is found for the AL09 desert region) in the GlobAEROSOL product are seen over ocean regions, in particular AO04 and AO06. Although we might expect the retrieval to be more prone to error over the brighter and more variable land surface, the highly variable aerosol loading found in the AO04 (which is subject to periodic dust outflow from the Sahara) and AO06 (which is dominated by outflow from both Asia and Africa), are clearly a challenge for the retrieval.

In addition to the uncertainty in the AOD retrieval itself, it is important that the sampling error due to the relatively sparse sampling of AATSR is also accounted for. The $512 \mathrm{~km}$ swath width of the AATSR instrument and the Sunsynchronous orbit of the ENVISAT platform combine to provide near-global coverage over three days. The short atmospheric lifetime of aerosols and their rapid near-source evolution mean that AATSR can entirely miss significant aerosol events.
To estimate the magnitude of this error, daily level 3 aerosol products from MODIS on board the Terra satellite have been used. MODIS-Terra is in a similar Sunsynchronous orbit to AATSR, but provides near global coverage on a daily basis. The level 3 aerosol product provides estimates of AOD at $550 \mathrm{~nm}$ on a $1^{\circ} \times 1^{\circ}$ lat-lon grid. The AATSR sampling error has been estimated by calculating two separate sets of regional, monthly-mean AOD datasets from eight years (2000-2008) of MODIS daily level 3 data, the first using all available MODIS data, while the second was sub-sampled to simulated the AATSR measurement pattern. The median monthly standard deviation of the difference between the resulting regional averages is given in Table 2 . Although monthly values of this uncertainty were used in the analysis, these median values are sufficient to show its scale and pattern.

It is clear from Table 2 that ocean regions generally show a much lower sampling error than continental regions, which is as expected due to the relative homogeneity of aerosol loading over the ocean compared to over land. This is further evidenced by the fact that the ocean regions with the lowest sampling error (AO02 and $\mathrm{AO} 08)$ are also those which are 
Table 2. The median sampling error in monthly mean AOD from MODIS when sub-sampled to resemble AATSR measurements.

\begin{tabular}{lc|cc}
\hline Region & Median error & Region & Median error \\
\hline AO01 & 0.006 & AL01 & 0.010 \\
AO02 & 0.002 & AL02 & 0.008 \\
AO03 & 0.007 & AL03 & 0.012 \\
AO04 & 0.006 & AL04 & 0.006 \\
AO05 & 0.004 & AL05 & 0.008 \\
AO06 & 0.005 & AL06 & 0.008 \\
AO07 & 0.003 & AL07 & 0.015 \\
AO08 & 0.002 & AL08 & 0.014 \\
AO09 & 0.013 & AL09 & 0.012 \\
AI01 & 0.004 & AL10 & 0.009 \\
AI02 & 0.012 & AL11 & 0.007 \\
\hline
\end{tabular}

most remote from continental sources of aerosol, while the Mediterranean (AO09) has the highest. The high error seen in the Antarctic region (AI02) results from particularly poor sampling when the region is only partially illuminated in early spring and late autumn. The monthly, regional AOD that results from this analysis, along with its associated uncertainty is shown in Fig. 2.

\subsection{Scattering properties}

Scattering properties and concentration profiles representative of each region were found in the literature and were used with the radiative transfer code to represent the aerosol. Details of these properties and their sources are given in Table 3. In the small number of instances where the literature did not provide representative properties or profiles, the authors have chosen values that are likely to be approximately representative, based on knowledge of aerosol sources and prevailing atmospheric conditions.

Figure 3 shows the vertical concentration profiles used in this study and their literature sources. In the absence of cloud or strong gradients in aerosol composition with height, the vertical profile of aerosol has only a minor impact on the radiance at the top and bottom of the atmosphere (Thomas et al., 2009b). If aerosol composition is not homogeneous with height (as may be the case with elevated dust or smoke layers), significant changes in TOA radiation (particularly over dark surfaces) may be observed. This is an additional source of error not included in the calculations performed here.

\subsection{Radiation model}

The radiative transfer code used to perform the calculations was the offline version of the Met Office unified model radiation scheme (Edwards and Slingo, 1996), henceforth referred to as ES96. The scheme has an adaptable spectral resolution and allows the aerosol scattering properties (single scattering albedo, extinction coefficient, and asymmetry parame- ter) to be defined across a number of different wavelength bands. For this study 6 bands covering $0.2-10 \mu \mathrm{m}$ in wavelength were used to calculate broadband fluxes, although the aerosol scattering properties were assumed to be spectrally invariant. This radiative transfer code, whilst not state of the art, was chosen as it represents the level of sophistication of radiative transfers in climate models, and thus uncertainties identified whilst using this code are likely to be particularly relevant for uncertainties in the subsequent prediction of climate response.

The atmospheric data used to drive the model - namely temperature, pressure, humidity, and ozone concentration were from the ECMWF ERA-Interim dataset (Dee et al., 2011). Trace gas concentrations $\left(\mathrm{CO}_{2}, \mathrm{CH}_{4}, \mathrm{O}_{3}\right.$, and $\left.\mathrm{N}_{2} \mathrm{O}\right)$ were taken from the IPCC AR4 (Forster et al., 2007) and were assumed to be well mixed. Surface albedos were also taken from the ERA-Interim dataset.

\section{Radiative calculations}

There are two possible approaches to producing regional, monthly estimates of radiative effect and forcing:

1. Relatively high (compared to the regional scale of the output) spatial and/or temporal resolution data on the atmospheric and surface state can be used in the radiative transfer code, and the resulting radiative fields averaged to produce the regional, monthly values.

2. The input data can be averaged over each region and month, and single runs of the radiative code used to produce the desired output.

The latter approach was taken for this work, both to reduce computational overheads and because much of the required input data were not available at high temporal or spatial resolution, with the result that high resolution radiative transfer would have yielded little additional information. Aerosol scattering properties and vertical profiles have until very recently only been available through infrequent field campaigns or sparse in situ measurements. In this study, and a regional average was produced from the relevant measurement campaigns, or from an analysis of the long term AERONET measurements.

To integrate the GlobAEROSOL AOD with the regional aerosol climatology given in Table 3 and Fig. 3, the concentration profiles were scaled to produce the required AOD value. Assuming the atmosphere is in hydrostatic balance, the aerosol optical depth is given by

$\tau_{\mathrm{a}}=\frac{k_{\mathrm{ext}}}{g} \int w_{\mathrm{s}} \mathrm{d} p$,

where $k_{\text {ext }}$ is the extinction coefficient of the aerosol, derived from Table $3, w_{\mathrm{s}}$ is the vertical aerosol mass-mixing ratio 


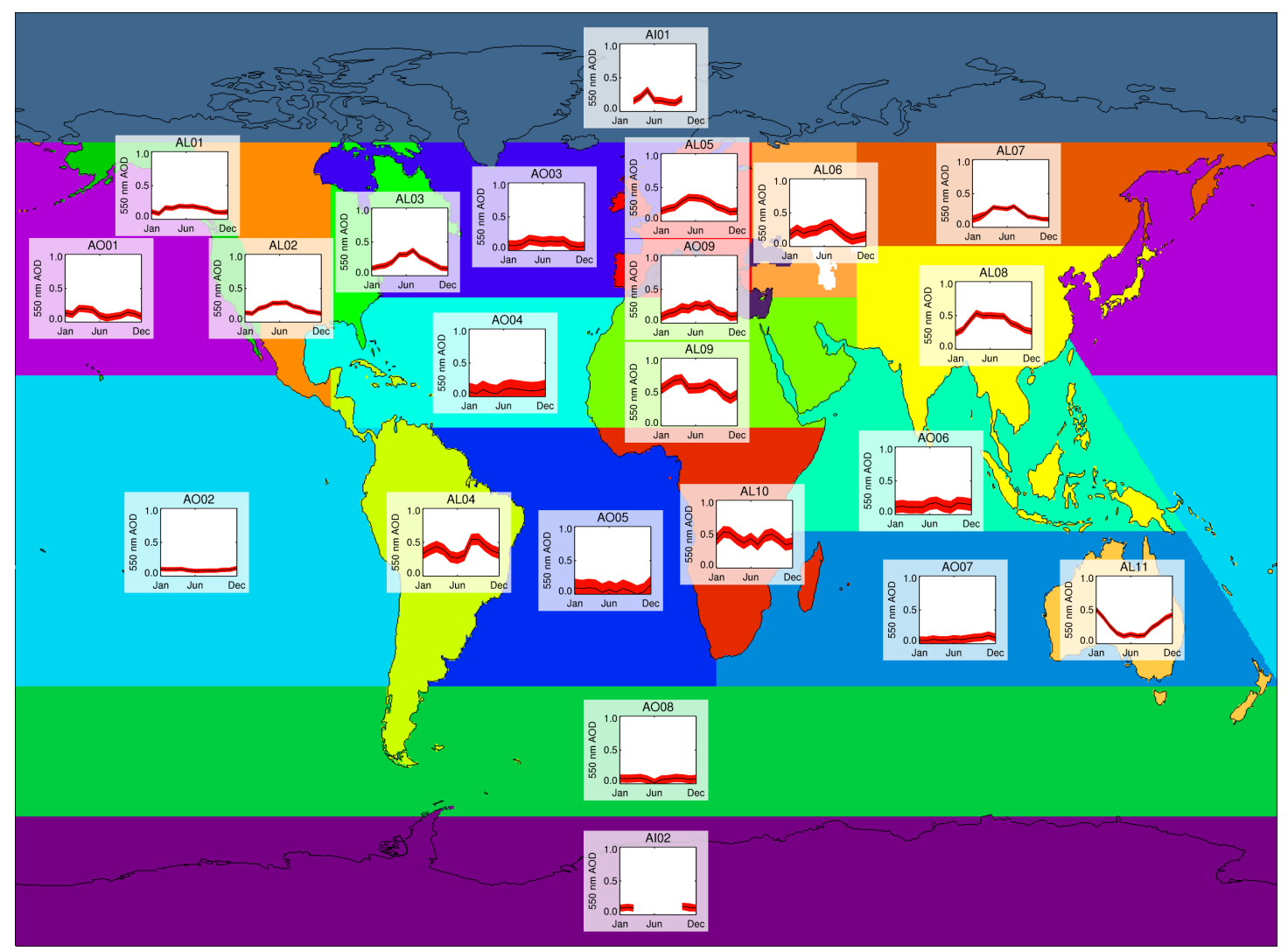

Fig. 2. Regional and monthly mean $550 \mathrm{~nm}$ AOD for 2006 from the GlobAEROSOL AATSR dataset, corrected for regional biases against AERONET. The red shaded areas denote the $\pm 1 \sigma$ uncertainty, including the error against AERONET and sampling error.

profile, $p$ is pressure, and $g$ is gravity. Equation (1) can be discretised and re-arranged to give:

$s=\frac{\tau_{\mathrm{a}} g}{k_{\mathrm{ext}} \Sigma w_{\mathrm{s}}^{\prime} \Delta p}$,

where the mass mixing ratio is now given by $w_{\mathrm{s}}=s \times w_{\mathrm{s}}^{\prime}$, where $w_{\mathrm{s}}^{\prime}$ is the normalised aerosol concentration profile and $s$ is a scaling factor, which is constant with pressure. The scaling parameter for each region and month can then be used to provide the ES96 with aerosol profiles, which are consistent with the observed AOD averages.

This approach ensures that the radiative transfer is run with the observed AOD and prescribed aerosol scattering properties and vertical profiles. However, as the prescribed properties are unlikely to be an exact match for the assumptions made in the GlobAEROSOL retrieval, the radiative transfer is unlikely to exactly reproduce the TOA radiance observed by the AATSR satellite, even if the surface reflectance assumptions are equivalent. This is a significant potential error in our approach and is dealt with by the "scattering properties" uncertainty term discussed in Sect. 4.

The ES96 was run over three solar zenith angles, both with and without aerosol, to provide diurnally averaged, clear sky, aerosol radiative effect (ARE), defined as:
$\Delta R=\left(F^{\downarrow}-F^{\uparrow}\right)_{\mathrm{a}}-\left(F^{\downarrow}-F^{\uparrow}\right)_{\text {clean }}$,

where $\Delta R$ is the aerosol radiative effect, $F^{\downarrow}$ and $F^{\uparrow}$ are the down-welling and up-welling fluxes respectively, while the subscripts denote calculations with and without aerosol present.

\section{Uncertainty analysis}

An important part of this study is the quantification of the uncertainty in the calculations. Several sources were considered: the effect of spatial and temporal averaging, uncertainty in the surface albedo, the spectral variability of aerosol scattering properties, uncertainty in the scattering properties themselves, and retrieval error. In order to map the uncertainties in these input parameters into the corresponding probability density function of radiative effect (which in turn defines its uncertainty) Monte-Carlo or Bayesian emulation approaches could be employed. However, due to computational limitations on the number of radiative-transfer calculations which could be performed, a full statistical analysis of all these error terms, with the exception of the AOD uncertainty 
Table 3. Aerosol scattering properties used in this study for each region, and their literture sources. Where two or more different properties are found, an average is taken.

\begin{tabular}{|c|c|c|c|}
\hline Region & Single Scattering Albedo & $k_{\text {scat }}\left[\mathrm{m}^{2} \mathrm{~g}^{-1}\right]$ & Assymetry parameter \\
\hline \multirow[t]{2}{*}{ AL01 } & 0.88 & 5.0 & 0.68 \\
\hline & 0.85 AERONET, 0.9 & Andrews et al. (2004) & 0.71 AERONET, 0.65 Andrews et al. (2004) \\
\hline \multirow[t]{2}{*}{ AL02 } & 0.88 & 5.0 & 0.68 \\
\hline & & & Shinozuka et al. (2007) \\
\hline \multirow[t]{2}{*}{ AL03 } & 0.96 & 5.0 & 0.63 \\
\hline & & & Shinozuka et al. (2007) \\
\hline \multirow[t]{2}{*}{ AL04 } & 0.92 & 3.3 & 0.63 \\
\hline & Dubovik et al. (2002) & Hobbs et al. (1997) & Dubovik et al. (2002) \\
\hline \multirow[t]{2}{*}{ AL05 } & 0.96 & 5.0 & 0.53 \\
\hline & Highwood (2010) & Highwood (2010) & Highwood (2010), Osborne et al. (2007) \\
\hline \multirow[t]{2}{*}{ AL06 } & 0.91 & 3.5 & 0.53 \\
\hline & Cook and Highwood (2004) & Osborne et al. (2007) & Highwood (2010), Osborne et al. (2007) \\
\hline \multirow[t]{2}{*}{ AL07 } & 0.95 & 1.5 & 0.68 \\
\hline & 0.89 AERONET, 0.94 Hess et al. (1998) & Hess et al. (1998) & AERONET \\
\hline \multirow[t]{4}{*}{ AL08 } & 0.89 & 3.8 & 0.69 \\
\hline & AERONET & Bates et al. (2006) & AERONET, \\
\hline & & (4.44 Continental, & Redemann et al. (2003) \\
\hline & & $\begin{array}{l}\text { 2.97 Continental and dust, } \\
\text { 4.07 All air masses) }\end{array}$ & \\
\hline \multirow[t]{2}{*}{ AL09 } & 0.98 & 0.85 & 0.68 \\
\hline & (McConnell et al., 2008) & & \\
\hline \multirow[t]{3}{*}{ AL10 } & 0.85 & 2.4 & 0.57 \\
\hline & 0.86 Haywood et al. (2003), & 3.8 Haywood et al. (2003), & 0.52 Haywood et al. (2003), \\
\hline & 0.84 Hess et al. (1998) & 1.8 Hess et al. (1998) & 0.62 Hess et al. (1998) \\
\hline \multirow[t]{2}{*}{ AL11 } & 0.86 & 4.3 & 0.68 \\
\hline & AERONET & Gras et al. (2001), Luhar et al. (2008) & (AERONET) \\
\hline \multirow[t]{3}{*}{$\mathrm{AO01}$} & 0.97 & 2.8 & 0.70 \\
\hline & 0.96 Bates et al. (2006), & 3.7 Bates et al. (2006), & AERONET - Gosan, \\
\hline & 0.99 Hess et al. (1998) & 2.0 Quinn et al. (1996) & Hess et al. (1998) \\
\hline \multirow[t]{2}{*}{$\mathrm{AO} 02$} & 0.99 & 1.4 & 0.70 \\
\hline & Hess et al. (1998) & Quinn et al. (1996) & Hess et al. (1998) \\
\hline \multirow[t]{3}{*}{$\mathrm{AO} 03$} & 0.97 & 3.7 & 0.70 \\
\hline & 0.95 Bates et al. (2006), & & AERONET - Mace Head \\
\hline & 0.98 AERONET-Mace Head & & \\
\hline \multirow[t]{3}{*}{$\mathrm{AO} 04$} & 0.91 & 3.3 & 0.66 \\
\hline & 0.98 McConnell et al. (2008), & 0.85 McConnell et al. (2008), & 0.68 McConnell et al. (2008), \\
\hline & 0.83 Léon et al. (2009) & 5.8 Léon et al. (2009) & 0.63 Léon et al. (2009) \\
\hline \multirow[t]{2}{*}{$\mathrm{AO} 05$} & 0.91 & 5.0 & 0.59 \\
\hline & Haywood et al. (2003) & Haywood et al. (2003) & Haywood et al. (2003) \\
\hline \multirow[t]{4}{*}{ AO06 } & 0.90 & 4.7 & 0.74 \\
\hline & 0.85 Bates et al. (2006), & Bates et al. (2006), & Bates et al. (2006), \\
\hline & Babu et al. (2010) (ocean), & & AERONET \\
\hline & 0.95 Bates et al. (2006) (subcontinent) & & \\
\hline \multirow[t]{2}{*}{$\mathrm{AO07}$} & 0.95 & 3.7 & 0.73 \\
\hline & AERONET & Bates et al. (2006) & AERONET \\
\hline \multirow[t]{2}{*}{$\mathrm{AO} 08$} & 0.99 & 3.4 & 0.65 \\
\hline & Quinn et al. (1996) & Quinn et al. (1996) & Quinn et al. (1996) \\
\hline AO09 & 0.89 & 3.3 & 0.66 \\
\hline & 0.85 Di Iorio et al. (2009) (summer), & Bryant et al. (2006) & AERONET \\
\hline & 0.87 Di Iorio et al. (2009) (winter) & & \\
\hline & 0.92 (summer), 0.93 (winter) AERONET & & \\
\hline AI01 & 0.98 & 2.2 & 0.71 \\
\hline & & Hess et al. (1998) & Hess et al. (1998) \\
\hline $\mathrm{AI} 02$ & 0.99 & 5.3 & 0.78 \\
\hline & Weller and Lampert (2008) & 5.0 (coastal) & Hess et al. (1998) \\
\hline & & 8.1 (biogenic sulphates) & \\
\hline & & 2.8 Hess et al. (1998) & \\
\hline
\end{tabular}




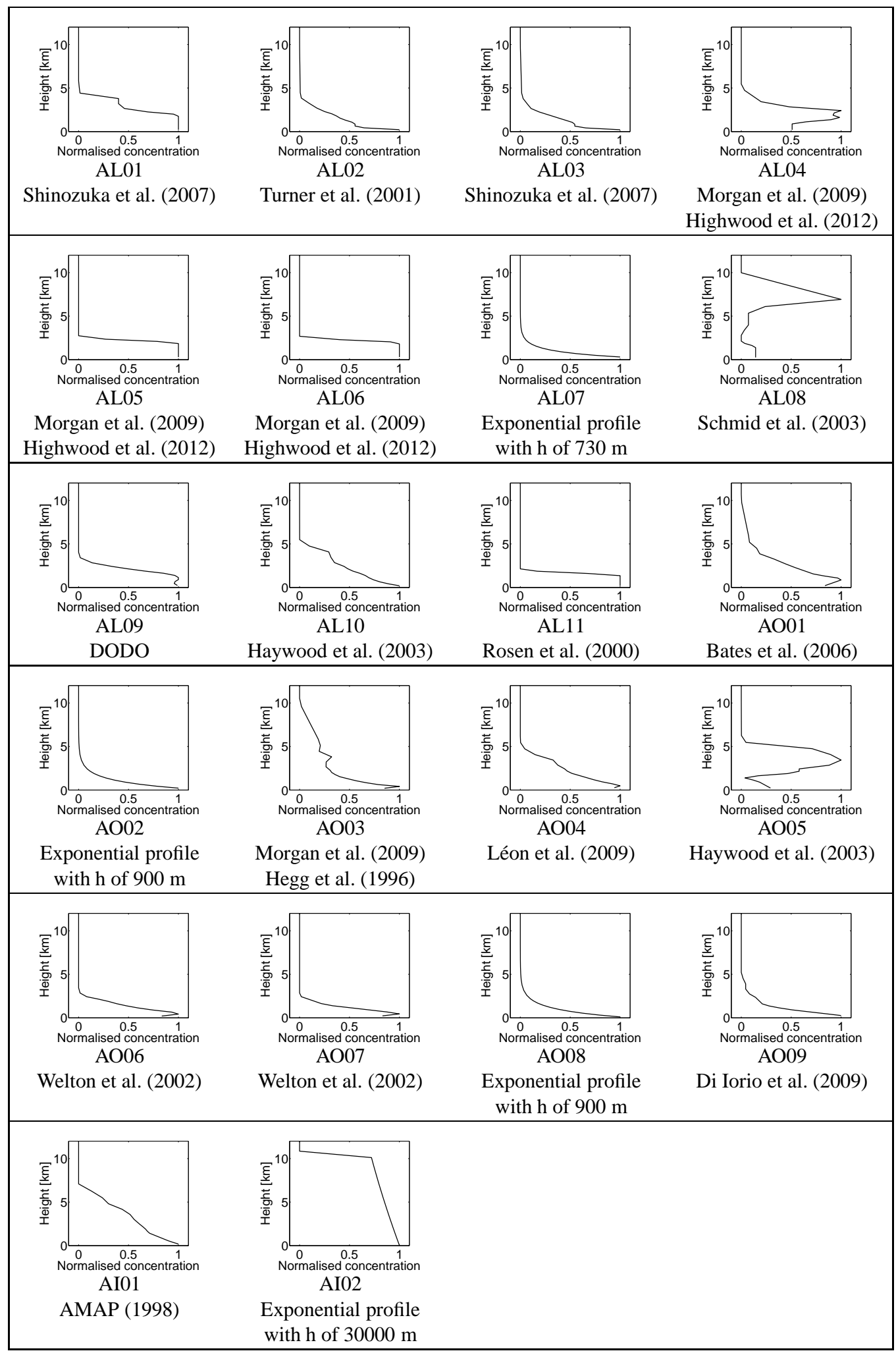

Fig. 3. Normalised aerosol concentration profiles used in this study for each region, and their literature sources. Where an exponential profile is used, $w_{s}^{\prime}=e^{-z / h}$ where $w_{s}^{\prime}$ is the normalised aerosol mass mixing ratio; $z$ is height and $h$ is the scale height, both in metres. 
described in Sect. 2.1, was not possible within the scope of this work. However, limited calculations were performed to provide estimates of the magnitude of these uncertainties, using a test dataset for April 2006. Five experiments were conducted and are described below.

- Spatial: $\left(\delta_{\mathrm{A}} \Delta R\right)$ the radiation calculations were performed at the resolution of the monthly GlobAEROSOL AOD fields $\left(1^{\circ} \times 1^{\circ}\right)$ and then the results were averaged to the regional scale. The aerosol scattering properties and concentration profiles remained at the regional scale. This provides an estimate of the error in the assumption of linearity made by calculating the radiative effect for averaged AOD fields (rather than averaging the radiative effect itself). In other words, the difference is that between:

$$
\begin{aligned}
\delta_{\mathrm{A}} \Delta R & =\left|\overline{\Delta R\left(\tau_{\mathrm{a}}(A)\right)}-\Delta R\left(\overline{\tau_{\mathrm{a}}(A)}\right)\right| \\
& =\left|\frac{\int_{A} \Delta R\left(\tau_{\mathrm{a}}(A)\right) \mathrm{d} A-\Delta R\left(\int_{A} \tau_{\mathrm{a}}(A) \mathrm{d} A\right)}{\int_{A} \mathrm{~d} A}\right|,
\end{aligned}
$$

where $A$ indicates the area covered by each region and the overline represents the mean value.

- Temporal: $\left(\delta_{\mathrm{t}} \Delta R\right)$ the regional average AOD was calculated daily and then the radiation calculations performed. The results were then averaged to the month timescale. The ERA-Interim atmospheric data remained a monthly average. This is mathematically the same as the spatial error term, only integrating in time rather than across each region.

- Scattering properties: $\left(\delta_{\mathrm{S}} \Delta R\right)$ OPAC aerosol scattering properties were used to scale the aerosol concentration in the radiation calculations. The aerosol type was defined by the "best type" from the GlobAEROSOL product. Under the assumption that this difference is representative of the uncertainty in the aerosol scattering properties, this further implies the assumption that the ARE responds approximately linearly to this perturbation:

$\delta_{\mathrm{S}} \Delta R \simeq\left|\Delta R(\omega, \beta, g)-\Delta R\left(\omega^{\prime}, \beta^{\prime}, g^{\prime}\right)\right|$,

where $\omega, \beta, g$ represent the aerosol properties assumed in the forcing calculations, and the primes indicate the OPAC values.

- Albedo: $\left(\delta_{\rho} \Delta R\right)$ the maximum and minimum values in each region of the surface albedo were used in the radiation calculations to assess the sensitivity to the surface albedo. It is likely that this is an over-estimate of this uncertainty, due to the use of the extreme values of the albedo for each region.

- Spectral variability: $\left(\delta_{\mathrm{s}} \Delta R\right)$ comparatively high spectral resolution (41 wavelengths between 280 and
$1000 \mathrm{~nm})$ OPAC aerosol scattering properties were averaged to the 6 band resolution and the radiation calculations done. Again the GlobAEROSOL "best type" was used to choose an aerosol type, and the results compared to the "scattering properties" experiment for consistency.

Incorporating these error terms into the overall uncertainty on the radiative forcing involves making some subjective decisions in how they should be treated. As we have only calculated the error estimates for a single month, we must assume that they are applicable for the whole year. We treat the spatial and temporal averaging uncertainties, the scattering properties uncertainty and the spectral variability uncertainty, as relative errors - that is to say that these errors are more likely to be some fraction of the AOD within a region, rather than a fixed value independent of AOD.

Conversely the ARE error due to uncertainty in the surface albedo is more likely to act as an absolute error, independent of the AOD, since the surface albedo is largely independent of the aerosol loading. These assumptions are, of course, approximate due to the non-linear response of the radiative transfer calculations to these perturbations, neglected correlations between terms (for example, uncertainty in the surface albedo could be expected to be less important at high loadings than low ones) and the unknown seasonal changes in the magnitude of these error terms.

Another decision which must be made is whether to treat these errors as random uncertainty or systematic errors. The simplest approach to combining independent random uncertainties on a value is to add the individual errors in quadrature, while purely systematic errors are additive. In reality, the error terms described above are unlikely to be either purely random or systematic, but the two cases can be considered limiting values of the true uncertainty.

The propagation of the uncertainty in AOD, discussed in Sect. 2.1.3, to ARE was performed in a similar manner to the averaging and modelling uncertainties. The ES96 code was called three times, for the mean AOD and the $\pm 1 \sigma$ values. The calculation at both $+1 \sigma$ and $-1 \sigma$ AOD provides an indication of the appropriateness of the linear error propagation used here. Except for the AO04, AO05 and AO06 regions, and in instances of very low ARE, the uncertainties in ARE are generally symmetrical within a few percent, suggesting the linear approximation is reasonable for the most part.

Application of the above assumptions leads to the following expressions for the overall uncertainty of the ARE for each region and month: 


$$
\begin{aligned}
\left(\delta_{\mathcal{R}} \Delta R\right)^{2}=\left(\delta_{\tau} \Delta R\right)^{2}+ & \left(\Delta R \frac{\delta_{\mathrm{A}} \Delta R}{\Delta R_{\text {April }}}\right)^{2} \\
+ & \left(\Delta R \frac{\delta_{\mathrm{t}} \Delta R}{\Delta R_{\text {April }}}\right)^{2} \\
+ & \left(\Delta R \frac{\delta_{\mathrm{s}} \Delta R}{\Delta R_{\text {April }}}\right)^{2} \\
& +\left(\delta_{\rho} \Delta R\right)^{2} \\
+ & \left(\Delta R \frac{\delta_{\mathrm{v}} \Delta R}{\Delta R_{\text {April }}}\right)^{2},
\end{aligned}
$$

where $\delta_{\tau} \Delta R$ is the uncertainty from the GlobAEROSOL AOD, $\Delta R$ is the value of ARE at each month, while $\Delta R_{\text {April }}$ is its value for the test month of April, and $\delta_{\mathcal{R}}$ indicates the assumption that all uncertainties are random; and

$$
\begin{aligned}
\delta_{\mathcal{S}} \Delta R=\delta_{\tau} \Delta R+ & \Delta R \frac{\delta_{\mathrm{A}} \Delta R}{\Delta R_{\text {April }}} \\
+ & \Delta R \frac{\delta_{\mathrm{t}} \Delta R}{\Delta R_{\text {April }}} \\
& +\Delta R \frac{\delta_{\mathrm{s}} \Delta R}{\Delta R_{\text {April }}} \\
& +\delta_{\rho} \Delta R \\
& +\Delta R \frac{\delta_{\mathrm{v}} \Delta R}{\Delta R_{\text {April }}}
\end{aligned}
$$

where $\delta_{\mathcal{S}}$ indicates that all errors are assumed to be purely systematic.

\section{Radiative forcing estimation}

In order to estimate the aerosol radiative forcing it is necessary to perform radiation calculations for pre-industrial aerosol loading. We have used the pre-industrial (for the year 1750) aerosol optical depth data from the AEROCOM project (Kinne et al., 2006), derived using the Oslo CTM2 (Myhre et al., 2009) and GISS MATRIX aerosol models, and assumed the scattering properties of each region have stayed unchanged from pre-industrial to present day (which is likely to result in an underestimate of the magnitude of the forcing). It is clear that any estimate of pre-industrial AOD is likely to be subject to significant, and unknown, biases, due to the lack of measurements or knowledge of primary aerosol and aerosol-precursor emission. Thus this calculation cannot be taken as a firm and well constrained estimate of radiative forcing, and has been included for the purposes of illustration alone.

Although several models contributed to the AEROCOMPRE experiment, only two provided AOD fields in their output, meaning that even inter-model variability cannot be accounted for in any meaningful way. Thus, although the uncertainty esimtates on ARE have been propagated into a uncertainty estimate in radiative forcing, no additional error has been included to account for the uncertainty in the preindustrial AOD, or the assumption of invariant aerosol properties. Thus the resulting uncertainty estimates can be considered reasonable for radiative effect and a lower bound for radiative forcing.
It should also be noted that, as discussed by Myhre (2009), the use of a model based estimate of pre-industrial AOD in the forcing calculations makes this estimate more like the model-derived estimates in Forster et al. (2007) than the satellite derived estimates contained therein, as these used estimates of the anthropogenic fraction of the observed AOD to estimate the forcing (Bellouin et al., 2005).

\section{Results and discussion}

This section is split into separate discussions of the uncertainty analysis, the ARE calculation results and the estimation of radiative forcing.

\subsection{Uncertainty analysis}

The uncertainties were calculated as described in Sect. 4 and are expressed as percentages changes between the test and reference calculations. Figure 4 shows the TOA and surface percentage differences for each experiment in each region. All sources of radiative transfer uncertainty considered generally cause a difference of less than $10 \%$ in the average ARE. The uncertainty at the surface is generally larger than that at TOA. Both the albedo and spectral variability effects are very small everywhere compared with the other sources of uncertainty.

In practice the assumption of random or systematic errors in the propagation of the individual uncertainties into the overall value results in a change of less than $5 \%$ in the ARE uncertainty, with the random error generally being the larger. Thus, the random uncertainty estimate has been used in displaying all results.

The largest changes in the ARE results are caused by the uncertainty in the regional AOD, the temporal and spatial averaging, and the scattering properties experiments. Although it is possible to perform the calculations at a higher spatial and temporal resolution, allowed by the aerosol optical depth retrieval, the uncertainty caused by the scattering properties is of comparable magnitude. Therefore until the scattering properties of aerosol are known at a greater spatial resolution the uncertainty in the radiative effect (and therefore forcing) calculations will not be significantly improved.

\subsection{Aerosol radiative effect calculations}

The results of the aerosol direct clear sky ARE calculations, driven by the bias corrected GlobAEROSOL AOD product, are given in Fig. 5. The annual mean and ARE and corresponding forcing for each region is presented in Table 4. The global, annual mean ARE from this analysis is $(-6.7 \pm 3.9) \mathrm{W} \mathrm{m}^{-2}$ at TOA and $(-12 \pm 6) \mathrm{W} \mathrm{m}^{-2}$ for the surface, which is in good agreement with previous estimates of this quantity (e.g. Zhao et al., 2011).

As would be expected, Fig. 5 shows that the ARE is negative for all regions at both TOA and surface, even in regions 
Table 4. Annual regional mean and $\pm 1 \sigma$ values (where $\sigma$ is the standard error) of the aerosol radiative effect and forcing for 2006 at the surface and TOA.

\begin{tabular}{|c|c|c|c|c|c|c|c|c|c|c|c|c|}
\hline \multirow[t]{2}{*}{ Region } & \multicolumn{3}{|c|}{ TOA ARE $\left[\mathrm{W} \mathrm{m}^{-2}\right]$} & \multicolumn{3}{|c|}{ Surface ARE $\left[\mathrm{W} \mathrm{m}^{-2}\right]$} & \multicolumn{3}{|c|}{ TOA Forcing $\left[\mathrm{W} \mathrm{m}^{-2}\right]$} & \multicolumn{3}{|c|}{ Surface Forcing $\left[\mathrm{W} \mathrm{m}^{-2}\right.$ ] } \\
\hline & $-1 \sigma$ & Mean & $+1 \sigma$ & $-1 \sigma$ & Mean & $+1 \sigma$ & $-1 \sigma$ & Mean & $+1 \sigma$ & $-1 \sigma$ & Mean & $+1 \sigma$ \\
\hline AL01 & -4.5 & -5.7 & -6.8 & -12 & -15 & -15 & -1.7 & -2.9 & -3.9 & -5.6 & -8.8 & -12 \\
\hline AL02 & -5.5 & -6.5 & -7.3 & -16 & -19 & -23 & -3.4 & -4.4 & -5.1 & -11 & -14 & -17 \\
\hline AL03 & -10 & -12 & -14 & -14 & -17 & -20 & -6.5 & -8.6 & -10 & -9.2 & -12 & -15 \\
\hline AL04 & -10 & -13 & -15 & -22 & -28 & -35 & -6.9 & -9.4 & -11 & -16 & -22 & -28 \\
\hline AL05 & -13 & -16 & -19 & -17 & -21 & -26 & -5.4 & -8.4 & -11 & -7.5 & -12 & -16 \\
\hline AL06 & -7.9 & -12 & -15 & -14 & -21 & -28 & -2.8 & -6.5 & -9.5 & -5.7 & -13 & -19 \\
\hline AL07 & -8.1 & -9.5 & -11 & -15 & -21 & -28 & -4.7 & -6.2 & -7.3 & -9.9 & -13 & -16 \\
\hline AL08 & -7.9 & -8.7 & -9.5 & -28 & -32 & -37 & -5.0 & -5.9 & -6.5 & -21 & -25 & -29 \\
\hline AL09 & -11 & -12 & -14 & -18 & -20 & -23 & -5.3 & -6.7 & -8.0 & -9.3 & -12 & -15 \\
\hline AL10 & -7.8 & -9.3 & -11 & -33 & -43 & -52 & -5.0 & -6.6 & -7.8 & -25 & -33 & -42 \\
\hline AL11 & -3.4 & -2.6 & -2.0 & -18 & -21 & -24 & -1.8 & -1.0 & -1.4 & -11 & -14 & -17 \\
\hline $\mathrm{AO} 01$ & -5.0 & -8.1 & -11 & -5.5 & -9.5 & -13 & 4.2 & 1.1 & -1.6 & 5.0 & 1.2 & -2.2 \\
\hline $\mathrm{AO} 02$ & -3.3 & -5.1 & -6.7 & -3.7 & -5.7 & -7.5 & 2.2 & 0.47 & -1 & 2.4 & 0.52 & -1.3 \\
\hline $\mathrm{AO} 03$ & -3.1 & -8.2 & -13 & -3.4 & -9.5 & -15 & 5.3 & 0.06 & -4.3 & 5.7 & -0.36 & -5.6 \\
\hline $\mathrm{AO} 04$ & 0.8 & -4.7 & -10 & 2.9 & -9.0 & -21 & 6.6 & 1.7 & -3.7 & 13 & 3.5 & -8.4 \\
\hline $\mathrm{AO} 05$ & 3.7 & -4.5 & -13 & 6.6 & -7.1 & -21 & 7.4 & 2.4 & -5.3 & 12 & 3.8 & -9.8 \\
\hline AO06 & -1.5 & -4.2 & -6.3 & -3.6 & -11 & -18 & 1.3 & -1.4 & -3.5 & 3.5 & -4.2 & -11 \\
\hline AO07 & -0.4 & -3.8 & -7.0 & -0.7 & -5.7 & -10 & 4.4 & 0.88 & -1.9 & 6.2 & 1.2 & -3.5 \\
\hline $\mathrm{AO} 08$ & -0.4 & -6.4 & -11 & -0.6 & -6.5 & -12 & 16 & 11 & 6.4 & 17 & 11 & 6.2 \\
\hline AO09 & -6.3 & -9.3 & -12 & -12 & -21 & -29 & 0.6 & -2.3 & -4.8 & 0.1 & -6.6 & -13 \\
\hline AI01 & & -14 & & & -14 & & & -10 & & & -11 & \\
\hline AI02 & -3.5 & -6.0 & -8.2 & -3.0 & -5.3 & -7.2 & -0.88 & -1.9 & -6.0 & -0.84 & -1.7 & -5.4 \\
\hline Global & -2.8 & -6.7 & -10 & -6.3 & -12 & -17 & 3.3 & -0.16 & -3.6 & 1.2 & -3.1 & -8.2 \\
\hline Global-A008 & & & & & & & 0.8 & -1.6 & -4.3 & -0.71 & -4.6 & -9.2 \\
\hline
\end{tabular}

of high surface reflectance (e.g. AL09, AI01 and AI02), where absorbing aerosol could potentially result in a positive effect. The only regions where the $1 \sigma$ uncertainty suggests that a positive ARE cannot be discounted are ocean regions with highly variable aerosol loadings, such as the Mid- and Southern-Atlantic. Given the low albedo of the ocean, it is physically unlikely the positive ARE could be considered realistic. It should also be noted that, as we are dealing with clear sky calculations only, the positive forcing potential of aerosol above cloud is not accounted for in these results.

The effect of aerosol absorption is apparent in Fig. 5, whereby aerosol absorption results in significantly stronger surface ARE than is seen at the top of atmosphere (Ramanathan et al., 2001). This effect is largest over land regions and is particularly associated with industrial or biomassburning pollution, and with the heavily polluted NorthernIndian Ocean and Mediterranean Sea (AO06 and AO09).

Most regions also show a seasonal cycle of ARE, with the strongest effect occurring during summer, which is in phase with the observed AOD cycle (Fig. 2). Not all regions show this pattern however, and in particular the Southern Hemisphere regions AL10 and AO06 (and AL04 to a lesser extent), which do not show a strong seasonal AOD cycle, show a strong ARE with a peak in winter. It is likely that the ARE cycle in these regions is dominated by the increase in solar zenith angle (resulting in a greater atmospheric path length) during winter. This, in combination with the weak ARE seen in other southern regions, results in a distinct annual cycle in global ARE, with the strongest effect occurring during northern summer. Although the calculations presented here are only for 2006, the regional pattern of AOD shows a significant level of inter-annual consistency, so it is likely that these patterns are representative over the longer term.

It is clear from Fig. 5 that the ARE produced by this methodology in many regions is reasonably well constrained, particularly at the TOA, where uncertainty in aerosol properties is less detrimental than at the surface. However, when the effects from different regions are combined to produce a global estimate, the result is quite poorly constrained (with an uncertainty of approximately $50 \%$ on the global, annual mean ARE).

It is important to remember that any uncertainty due to the radiative transfer code itself is not included here. However, the code used has recently been included in an intercomparison study by Randles et al. (2012), and this demonstrated that the uncertainty compared to state-of-the-art radiative transfer models is likely around $1-2 \%$ for the TOA radiative flux. This is considerably smaller than most of the other sources 


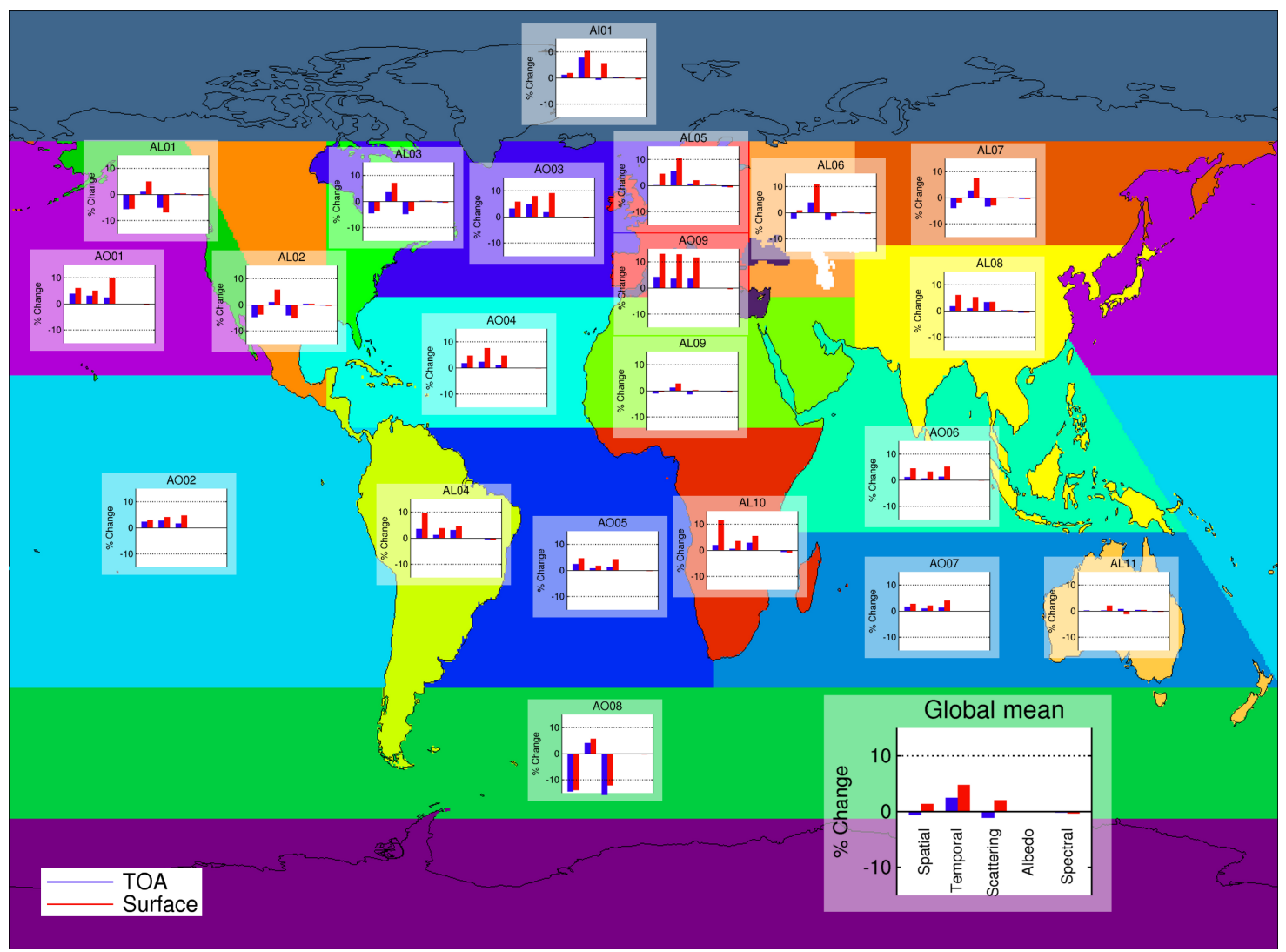

Fig. 4. Percentage differences in TOA and surface ARE for each experiment in each region calculated during April 2007. The plot in the lower left hand corner shows the global mean difference and also illustrates what each bar represents. The tests were not carried out for AI02 due to unavailability of data for this region in April.

considered here. For the surface, the intercomparison suggests that this code may underestimate the diffuse downward flux by around $10 \%$ and this could contribute an additional uncertainty to those in this paper.

\subsection{Clear-sky, direct aerosol forcing estimate}

If the radiative forcing is calculated (using 1750 AOD estimates from the AEROCOM Pre experiment), the resulting regional-monthly patterns look generally similar to the ARE for most regions. In regions with the strongest forcing estimates (e.g. AL04, AL08, AL10), the value is $80-90 \%$ of the observed radiative effect. Most ocean regions do not show significant forcings, partially because regions where such a forcing might be expected (e.g. the AO03-AO05 and AO03) also have poorly constrained ARE.

The developed industrial regions (AL01, AL03, AL05, AL06 and AO09) all show a distinct pattern in the radiative forcing where the forcing is far stronger in the summer months and approaches zero during the winter (in patterns similar to that of the ARE for these regions in Fig. 5), whereas the developing world shows a much more consistent forcing throughout the year. This pattern is due to a combi- nation of the regional variation in seasonal cycle of insolation, and the seasonal cycle in AOD. One potential contributor to the latter effect is that aerosol loading in developed regions is generally dominated by photo-chemical production of secondary aerosol, whereas the primary aerosol production, such as from biomass burning, is more important in developing regions.

The only systematic positive forcings are seen over the ocean, with a large positive forcing over the Southern Ocean (AO08). This is because the AEROCOM pre-industrial AOD is larger than that observed in 2006. However, the model derived AOD for 2000 is also much larger than the 2006 GlobAEROSOL estimate and this suggests a systematic bias between observations and models in this region rather than a real positive forcing. It is possible that this bias is a result of poor characterisation of sea-salt aerosol in the models, which is a recognised problem with many aerosol-chemical transport models (e.g. Jaeglé et al., 2011; Smirnov et al., 2011).

As shown in Table 4, the estimated annual global mean clear sky direct aerosol radiative forcing is $(-0.16 \pm 3.5) \mathrm{W} \mathrm{m}^{-2}$ at the TOA and $(-3.1 \pm 5.1) \mathrm{W} \mathrm{m}^{-2}$ at the surface. It should be remembered that the uncertainty 


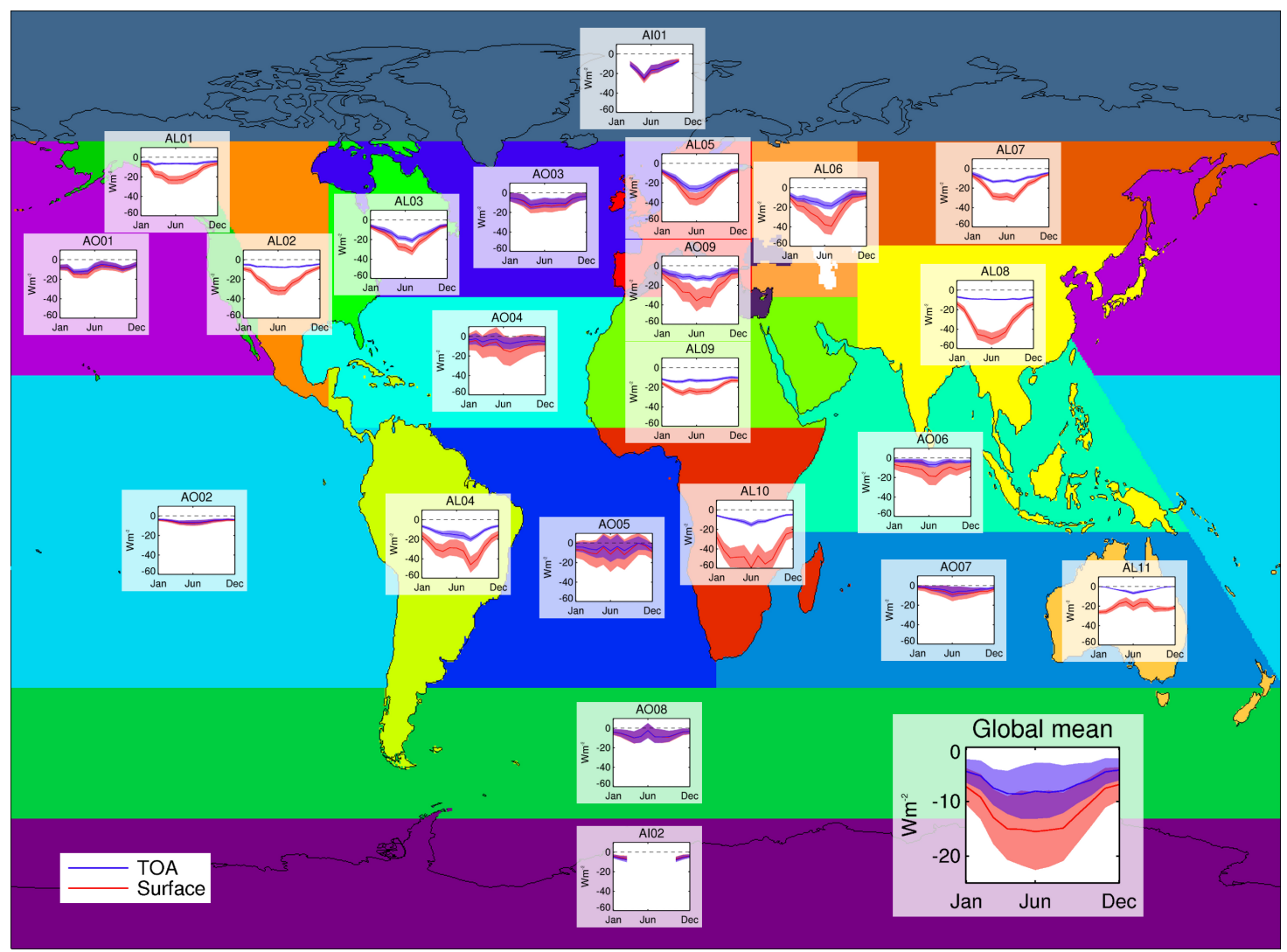

Fig. 5. Regional and monthly mean clear sky aerosol radiative effect (in $\mathrm{W} \mathrm{m}^{-2}$ ) calculated after bias correcting the $2006 \mathrm{GlobAEROSOL}$ aerosol optical depth retrievals compared with AERONET. The shading represents the uncertainty and the plot in the lower right corner shows the global mean.

estimates given on these values do not include the uncertainty in pre-industrial AOD or the error due to the assumption of invariant aerosol properties from pre-industrial to present times. Even without accounting for these sources of error, which could well be the largest in the calculations, the global mean forcing is very poorly constrained. As with the ARE results, this is partially due to the global annual mean value being the combination of regional-monthly values with a much greater magnitude.

The final row of Table 4 presents the forcing value if the unreasonable high positive value for the AO08 region is neglected by setting it to zero in the averaging. This produces global forcing values of $(-1.6 \pm 2.5) \mathrm{W} \mathrm{m}^{-2}$ and $(-4.6 \pm 4.2) \mathrm{W} \mathrm{m}^{-2}$ respectively. These values are probably more realistic estimates of the global forcing, as the remoteness of the AO08 region means we would expect little anthropogenic change in its aerosol loading. However, it is clear from the large uncertainties, even though errors in the preindustrial aerosol have been neglected, that the methodolgy applied here does not provide a reliable constraint on the global clear-sky, direct aerosol forcing.

\section{Conclusions}

In this study the monthly clear sky direct aerosol radiative effect and forcing were calculated over 22 regions, including an extensive exploration of likely sources of error in these calculations.

The globally and annually averaged clear-sky direct aerosol radiative effect was found to be $(-6.7 \pm 3.9) \mathrm{W} \mathrm{m}^{-2}$ at the TOA and $(-12 \pm 6) \mathrm{W} \mathrm{m}^{-2}$ at the surface. The corresponding forcings were estimated to be $(-0.16 \pm 3.5) \mathrm{W} \mathrm{m}^{-2}$ and $(-3.1 \pm 5) \mathrm{W} \mathrm{m}^{-2}$ respectively, neglecting uncertainty in the pre-industrial aerosol properties and loading used. If the forcing over the Southern Ocean is taken to be zero, as opposed to the anomalously strong positive forcing discussed in Sect. 6, these figures drastically change to $(-1.6 \pm 2.5) \mathrm{W} \mathrm{m}^{-2}$ and $(-4.6 \pm 4.2) \mathrm{W} \mathrm{m}^{-2}$ respectively.

Previous satellite based clear-sky aerosol TOA forcing estimates have ranged from $(-1.9 \pm 0.3) \mathrm{W} \mathrm{m}^{-2}$ (over ocean only) to $-1.3 \mathrm{~W} \mathrm{~m}^{-2}$, with estimates of all-sky direct forcing being approximately half this (Forster et al., 2007). Model estimates of the clear-sky TOA forcing provide an ensemble estimate $(-0.66 \pm 0.24) \mathrm{W} \mathrm{m}^{-2}$, based on a sample of 12 
models (Schulz et al., 2006). While the results presented here are in reasonable agreement with these previous estimates, especially if the positive forcing found in the Southern Ocean is discounted, the uncertainty of our estimate is considerably larger than previous approaches.

The dominant source of uncertainty in the ARE calculations is regionally dependant. In some regions the uncertainty in the retrieved monthly mean AOD field, as determined from AERONET comparisons, can be on the order of $100 \%$, whereas the sampling and modelling errors dominate in regions where the AOD is better constrained. The largest error contributors in converting the daily, $1 \times 1^{\circ}$ AOD fields to monthly, regional radiative effect values are the spatial and temporal averaging of AOD, and scattering properties used both to scale the aerosol concentration profiles and simulate the radiative fluxes. In addition to the need for continued improvements in the retrieval of aerosol properties from space whether it be through instruments more specifically designed for the task or through algorithm improvements - the key to reducing the uncertainty in the estimates of aerosol radiative forcing is better characterising of aerosol scattering properties, and more detailed aerosol type categorisations. Thus improving our knowledge of direct aerosol radiative forcing requires improvements in satellite remote sensing, in situ measurement and global modelling (Kahn, 2012). This will not only improve the simulation of the radiative impact of the aerosol, but also the retrieval of the optical depth, as the retrieval forward models themselves rely on accurate radiative transfer.

Within the GlobAEROSOL product the vast majority of aerosol is categorised either as background "maritime" or "continental", with small areas of dust or biomass burning. This level of aerosol type characterisation reflects limited information on aerosol type available from AATSR measurements, with different aerosols only becoming distinguishable in relatively extreme events associated with high AOD. Such products would clearly benefit from improved characterisation of the properties and spatio-temporal distribution of typical atmospheric aerosols.

AERONET almucantar retrievals, results from which have been included in the aerosol characterisation in this work (Table 3 and Fig. 3), are a valuable resource for providing ongoing characterisation of aerosol at a wide range of sites. These measurements form the basis for the aerosol properties used in an increasing number of satellite aerosol products (e.g. Levy et al., 2007; Martonchik et al., 2009; Sayer et al., 2012). However, these measurements are themselves based on remote sensing (better constrained than satellite products though they are) and do not provide truly global coverage (Shi et al., 2011). Thus the need for continued in situ measurement campaigns and aerosol-CTM modelling remains in constraining aerosol properties on a global scale.

Although the uncertainty in the global ARE calculated in this work is considerably higher than that given by previous studies, it is probably more representative of our knowl- edge of the direct aerosol radiative effect, and offers a lower bound on the uncertainty in the forcing, as the uncertainty in pre-industrial aerosol loading is unknown and has not been accounted for in our calculations. However, the region analysis clearly shows that the global mean obscures much of the temporal and spatial variability of ARE and aerosol forcing. Over some regions TOA ARE and forcings of the order of $-10 \mathrm{~W} \mathrm{~m}^{-2}$ have been calculated, with annual variability of the same magnitude. Furthermore, many regions show ARE which are well constrained, despite the uncertainty in the global mean.

Acknowledgements. This work was supported by the Natural Environment Research Council Appraising the Direct Impacts of Aerosol on Climate (ADIENT) project (grant number NE/E011187/1). We also gratefully acknowledge ESA for the use of GlobAEROSOL data, the principal investigators of the AERONET sites utilised in this study, NASA Goddard for providing access to the AERONET data, and the members of AEROCOM for providing the pre-industrial aerosol model data.

Edited by: F. Yu

\section{References}

AMAP: AMAP Assessment Report: Arctic Pollution Issues, Tech. rep., Arctic Monitoring and Assessment Programme, Oslo, Norway, 1998.

Andrews, E., Sheridan, P. J., Ogren, J. A., and Ferrare, R.: In situ aerosol profiles over the Southern Great Plains cloud and radiation test bed site: 1. Aerosol optical properties, J. Geophys. Res., 109, D06208, doi:10.1029/2003JD004025, 2004.

Babu, S., Krishna Moorthy, K., and Nair, V.: Large gradients in aerosol induced atmospheric heating rate over oceanic regions around India: Results from the ICARB Experiment of ISROGBP, in: 38th COSPAR Scientific Assembly, vol. 38, p. 52, 2010.

Bates, T. S., Anderson, T. L., Baynard, T., Bond, T., Boucher, O., Carmichael, G., Clarke, A., Erlick, C., Guo, H., Horowitz, L., Howell, S., Kulkarni, S., Maring, H., McComiskey, A., Middlebrook, A., Noone, K., O’Dowd, C. D., Ogren, J., Penner, J., Quinn, P. K., Ravishankara, A. R., Savoie, D. L., Schwartz, S. E., Shinozuka, Y., Tang, Y., Weber, R. J., and Wu, Y.: Aerosol direct radiative effects over the northwest Atlantic, northwest Pacific, and North Indian Oceans: estimates based on in-situ chemical and optical measurements and chemical transport modeling, Atmos. Chem. Phys., 6, 1657-1732, doi:10.5194/acp-6-1657-2006, 2006.

Bellouin, N., Boucher, O., Haywood, J., and Reddy, M.: Global estimate of aerosol direct radiative forcing from satellite measurements, Nature, 438, 1138-1141, 2005.

Bellouin, N., Jones, A., Haywood, J., and Christopher, S.: Updated estimate of aerosol direct radiative forcing from sateellite observations and comparison against the Hadley Centre climate model, J. Geophys. Res., 113, D10205, doi:10.1029/2007JD009385, 2008.

Boer, G. and Yu, B.: Climate sensitivity and response, Climate Dynam., 20, 415-429, 2003. 
Bryant, C., Eleftheriadis, K., Smolik, J., Zdimal, V., Mihalopoulos, N., and Colbeck, I.: Optical properties of aerosols over the eastern Mediterranean, Atmos. Environ., 40, 6229-6244, 2006.

Cook, J. and Highwood, E.: Climate response to tropospheric absorbing aerosols in an intermediate general-circulation model, Q. J. Roy. Meteorol Soc., 130, 175-191, 2004.

Dee, D., Uppala, S., Simmons, A., Berrisford, P., Poli, P., Kobayashi, S., Andrae, U., Balmaseda, M., Balsamo, G., Bauer, P., Bechtold, P., Beljaars, A., van de Berg, L., Bidlot, J., Bormann, N., Delsol, C., Dragani, R., Fuentes, M., Geer, A., Haimberger, L., Healy, S. B., Hersbach, H., Hólm, E. V., Isaksen, L., Kållberg, P., Köhler, M., Matricardi, M., McNally, A., MongeSanz, B., Morcrette, J.-J., Park, B.-K., Peubey, C., de Rosnay, P., Tavolato, C., Thépaut, J.-N., and Vitart, F.: The ERA-Interim reanalysis: configuration and performance of the data assimilation system, Q. J. Roy. Meteorol. Soc., 137, 553-597, 2011.

Di Iorio, T., di Sarra, A., Sferlazzo, D., Cacciani, M., Meloni, D., Monteleone, F., Fuà, D., and Fiocco, G.: Seasonal evolution of the tropospheric aerosol vertical profile in the central Mediterranean and role of desert dust, J. Geophys. Res., 114, D02201, doi:10.1029/2008JD010593, 2009.

Dubovik, O., Holben, B., Eck, T., Smirnov, A., Kaufman, Y., King, M., Tanré, D., and Slutsker, I.: Variability of absorption and optical properties of key aerosol types observed in worldwide locations, J. Atmos. Sci., 59, 590-608, 2002.

Edwards, J. M. and Slingo, A.: Studies with a flexible new radiation code. I: Choosing a configuration for a large-scale model, Q. J. Roy. Meteorol Soc., 122, 689-719, doi:10.1256/smsqj.53106, 1996.

Forster, P., Ramaswamy, V., Artaxo, P., Berntsen, T., Betts, R., Fahey, D., Haywood, J., Lean, J., Lowe, D., Myhre, G., Nganga, J., Prinn, R., Raga, G., Schulz, M., and Dorland, R. V.: Changes in atmospheric constituents and in radiative forcing, in: Climate Change 2007: The Physical science basis. Contribution of Working Group I to the Fourth assessment report of the Intergovernmental Panel on Climate Change, edited by: Solomon, S., Qin, D., Manning, M., Chen, Z., Marquis, M., Averyt, K. B., Tignor, M., and Miller, H. L., Cambridge University Press, Cambridge, United Kingdom and New York, NY, USA, 2007.

Gras, J., Keywood, M., and Ayers, G.: Factors controlling wintertime aerosol light scattering in Launceston, Tasmania, Atmos. Environ., 35, 1881-1889, 2001.

Haywood, J., Osborne, S., Francis, P., Keil, A., Formenti, P., Andreae, M., and Kaye, P.: The mean physical and optical properties of regional haze dominated by biomass burning aerosol measured from the C-130 aircraft during SAFARI 2000, J. Geophys. Res., 108, 8473, doi:10.1029/2002JD002226, 2003.

Hegg, D., Covert, D., Rood, M., and Hobbs, P.: Measurements of aerosol optical properties in marine air, J. Geophys. Res., 101, 12893-12996.

Hess, M., Koepke, P., and Schult, I.: Optical properties of aerosols and clouds: The software package OPAC, B. Am. Meteorol. Soc., 79, 831-844, 1998.

Highwood, E. J., Northway, M. J., McMeeking, G. R., Morgan, W. T., Liu, D., Osborne, S., Bower, K., Coe, H., Ryder, C., and Williams, P.: Aerosol scattering and absorption during the EUCAARI-LONGREX flights of the Facility for Airborne Atmospheric Measurements (FAAM) BAe-146: can measurements and models agree?, Atmos. Chem. Phys., 12, 7251-7267, doi:10.5194/acp-12-7251-2012, 2012.

Hobbs, P., Reid, J., Kotchenruther, R., Ferek, R., and Weiss, R.: Direct radiative forcing by smoke from biomass burning, Science, 275, 1777-1778, 1997.

Ichoku, C., Chu, D. A., Mattoo, S., Kaufman, Y. J., Remer, L. A., Tanre, D., Slutsker, I., and Holben, B. N.: A spatio-temporal approach for global validation and analysis of MODIS aerosol products, Geophys. Res. Lett., 29, 1616, doi:10.1029/2001GL013206, 2002.

Jaeglé, L., Quinn, P. K., Bates, T. S., Alexander, B., and Lin, J.-T.: Global distribution of sea salt aerosols: new constraints from in situ and remote sensing observations, Atmos. Chem. Phys., 11, 3137-3157, doi:10.5194/acp-11-3137-2011, 2011.

Kahn, R. A.: Reducing the uncertainties in direct aerosol radiative forcing, Surv. Geophys., 33, 701-721, doi:10.1007/s10712-0119153-z, 2012.

Kinne, S., Lohmann, U., Feichter, J., Schulz, M., Timmreck, C., Ghan, S., Easter, R., Chin, M., Ginoux, P., Takemura, T., Tegen, I., Koch, D., Herzog, M., Penner, J., Pitari, G., Holben, B., Eck, T., Smirnov, A., Dubovik, O., Slutsker, I., Tanre, D., Torres, O., Mishchenko, M., Geogdzhayev, I., Chu, D. A., and Kaufman, Y.: Monthly averages of aerosol properties: A global comparison among models, satellite data, and AERONET ground data, J. Geophys. Res., 108, 4634, doi:10.1029/2001JD001253, 2003.

Kinne, S., Schulz, M., Textor, C., Guibert, S., Balkanski, Y., Bauer, S. E., Berntsen, T., Berglen, T. F., Boucher, O., Chin, M., Collins, W., Dentener, F., Diehl, T., Easter, R., Feichter, J., Fillmore, D., Ghan, S., Ginoux, P., Gong, S., Grini, A., Hendricks, J., Herzog, M., Horowitz, L., Isaksen, I., Iversen, T., Kirkevåg, A., Kloster, S., Koch, D., Kristjansson, J. E., Krol, M., Lauer, A., Lamarque, J. F., Lesins, G., Liu, X., Lohmann, U., Montanaro, V., Myhre, G., Penner, J., Pitari, G., Reddy, S., Seland, O., Stier, P., Takemura, T., and Tie, X.: An AeroCom initial assessment - optical properties in aerosol component modules of global models, Atmos. Chem. Phys., 6, 1815-1834, doi:10.5194/acp-6-1815-2006, 2006.

Léon, J.-F., Derimian, Y., Chiapello, I., Tanré, D., Podvin, T., Chatenet, B., Diallo, A., and Deroo, C.: Aerosol vertical distribution and optical properties over M'Bour $\left(16.96^{\circ} \mathrm{W} ; 14.39^{\circ} \mathrm{N}\right)$, Senegal from 2006 to 2008, Atmos. Chem. Phys., 9, 9249-9261, doi:10.5194/acp-9-9249-2009, 2009

Levy, R. C., Remer, L. A., Mattoo, S., Vermote, E., and Kaufman, Y.: Second-generation operational algorithm: Retrieval of aerosol properties over land from inversion of Moderate Resolution Imaging Spectroradiometer spectral reflectance, J. Geophys. Res., 112, D13211, doi:10.1029/2006JD007811, 2007.

Levy, R. C., Remer, L. A., Kleidman, R. G., Mattoo, S., Ichoku, C., Kahn, R., and Eck, T. F.:Global evaluation of the Collection 5 MODIS dark-target aerosol products ofver land, Atmos. Chem. Phys., 10, 10399-10420, doi:10.5194/acp-10-10399-2010, 2010.

Luhar, A., Mitchell, R., Meyer, C., Qin, Y., Campbell, S., Gras, J., and Parry, D.: Biomass burning emissions over northern Australia constrained by aerosol measurements: II-Model validation, and impacts on air quality and radiative forcing, Atmos. Environ., 42, 1647-1664, 2008.

Martonchik, J., Kahn, R., and Diner, D.: Satellite aerosol remote sensing over land, chap. Retrieval of aerosol properties over alnd using MISR, Springer-Praxis, 2009. 
McConnell, C., Highwood, E., Coe, H., Formenti, P., Anderson, B., Osborne, S., Nava, S., Desboeufs, K., Chen, G., and Harrison, M.: Seasonal variations of the physical and optical characteristics of Saharan dust: Results from the Dust Outflow and Deposition to the Ocean (DODO) experiment, J. Geophys. Res., 113, D14S05, doi:10.1029/2007JD009606, 2008.

Morgan, W. T., Allan, J. D., Bower, K. N., Capes, G., Crosier, J., Williams, P. I., and Coe, H.: Vertical distribution of sub-micron aerosol chemical composition from North-Western Europe and the North-East Atlantic, Atmos. Chem. Phys., 9, 5389-5401, doi:10.5194/acp-9-5389-2009, 2009.

Myhre, G.: Consistency between satellite-derived and modeled estimates of the direct aerosol effect, Science, 325, 187-190, 2009.

Myhre, G., Berglen, T. F., Johnsrud, M., Hoyle, C. R., Berntsen, T. K., Christopher, S. A., Fahey, D. W., Isaksen, I. S. A., Jones, T. A., Kahn, R. A., Loeb, N., Quinn, P., Remer, L., Schwarz, J. P., and Yttri, K. E.: Modelled radiative forcing of the direct aerosol effect with multi-observation evaluation, Atmos. Chem. Phys., 9, 1365-1392, doi:10.5194/acp-9-1365-2009, 2009.

Osborne, S. R., Haywood, J. M., and Bellouin, N.: In situ and remote-sensing measurements of the mean microphysical and optical properties of industrial pollution aerosol during ADRIEX, Q. J. Roy. Meteorol Soc., 133, 17-32, 2007.

Poulsen, C., Siddans, R., Thomas, G., Sayer, A., Grainger, R., Perez-Navarro, O., Portela-Arjona, O., and Deschamps, P.-Y.: ESA GlobAEROSOL: Final validation and intercomparison report, Tech. Rep. 3.2, European Space Agency, available online at: http://www.globaerosol.info/docs/globaer_fvir_v3p2.pdf (last access: July 2012), 2009.

Quinn, P., Kapustin, V., Bates, T., and Covert, D.: Chemical and optical properties of marine boundary layer aerosol particles of the mid-Pacific in relation to sources and meteorological transport, J. Geophys. Res., 101, 6931-6951, 1996.

Ramanathan, V., Crutzen, P., Lelieveld, J., Mitra, A., Althausen, D., Anderson, J., Andreae, M., Cantrell, W., Cass, G., Chung, C., Clarke, A., Coakley, J., Collins, W., Conant, W., Dulac, F., Heintzenberg, J., Heymsfield, A., Holben, B., Howell, S., Hudson, J., Jayaraman, A., Kiehl, J., Krishnamurti, T., Lubin, D., McFarquhar, G., Novakov, T., Ogren, J., Podgorny, I., Prather, K., Priestley, K., Prospero, J., Quinn, P., Rajeev, K., Rasch, P., Rupert, S., Sadourny, R., Satheesh, S., Shaw, G., Sheridan, P., and Valero, F.: Indian Ocean Experiment: An integrated analysis of the climate forcing and effects of the great Indo-Asian haze, J. Geophys. Res., 106, 28371-28398, doi:10.1029/2001JD900133, 2001.

Randles, C. A., Kinne, S., Myhre, G., Schulz, M., Stier, P., Fischer, J., Doppler, L., Highwood, E., Ryder, C., Harris, B., Huttunen, J., Ma, Y., Pinker, R. T., Mayer, B., Neubauer, D., Hitzenberger, R., Oreopoulos, L., Lee, D., Pitari, G., Di Genova, G., Quaas, J., Rose, Fred G., Kato, S., Rumbold, S. T., Vardavas, I., Hatzianastassiou, N., Matsoukas, C., Yu, H., Zhang, F., Zhang, H., and $\mathrm{Lu}$, P.: Intercomparison of shortwave radiative transfer schemes in global aerosol modeling: results from the AeroCom Radiative Transfer Experiment, Atmos. Chem. Phys. Discuss., 12, 3263132706, doi:10.5194/acpd-12-32631-2012, 2012.

Redemann, J., Masonis, S., Schmid, B., Anderson, T., Russell, P., Livingston, J., Dubovik, O., and Clarke, A.: Clear-column closure studies of aerosols and water vapor aboard the NCAR C-130 during ACE-Asia, 2001, J. Geophys. Res, 108, 8655,
doi:10.1029/2003JD003442, 2003.

Remer, L. A. and Kaufman, Y. J.: Aerosol direct radiative effect at the top of the atmosphere over cloud free ocean derived from four years of MODIS data, Atmos. Chem. Phys., 6, 237-253, doi:10.5194/acp-6-237-2006, 2006.

Rosen, J., Young, S., Laby, J., Kjome, N., and Gras, J.: Springtime aerosol layers in the free troposphere over Australia: Mildura Aerosol Tropospheric Experiment (MATE 98), J. Geophys. Res., 105, 17833-17842, 2000.

Sayer, A., Hsu, N., Bettenhausen, C., Ahmad, Z., Holben, B., Smirnov, A., Thomas, G., and Zhang, J.: SeaWiFS Ocean Aerosol Retrieval (SOAR): Algorithm, validation, and comparison with other data sets, J. Geophys. Res., 117, D03206, doi:10.1029/2011JD016599, 2012.

Schmid, B., Hegg, D. A., Wang, J., Bates, D., Redemann, J., Russell, P. B., Livingston, J. M., Jonsson, H. H., Welton, E. J., Seinfeld, J. H., Flagan, R. C., Covert, D. S., Dubovik, O., and Jefferson, A.: Column closure studies of lower tropospheric aerosol and water vapor during ACE-Asia using airborne Sun photometer and airborne in situ and ship-based lidar measurements, J. Geophys. Res., 108, 8656, doi:10.1029/2002JD003361, 2003.

Schulz, M., Textor, C., Kinne, S., Balkanski, Y., Bauer, S., Berntsen, T., Berglen, T., Boucher, O., Dentener, F., Guibert, S., Isaksen, I. S. A., Iversen, T., Koch, D., Kirkevåg, A., Liu, X., Montanaro, V., Myhre, G., Penner, J. E., Pitari, G., Reddy, S., Seland, $\varnothing .$, Stier, P., and Takemura, T.: Radiative forcing by aerosols as derived from the AeroCom present-day and pre-industrial simulations, Atmos. Chem. Phys., 6, 5225-5246, doi:10.5194/acp-65225-2006, 2006.

Shi, Y., Zhang, J., Reid, J. S., Hyer, E. J., Eck, T. F., Holben, B. N., and Kahn, R. A.: A critical examination of spatial biases between MODIS and MISR aerosol products - application for potential AERONET deployment, Atmos. Meas. Tech., 4, 2823 2836, doi:10.5194/amt-4-2823-2011, 2011.

Shinozuka, Y., Clarke, A., Howell, S., Kapustin, V., McNaughton, C., Zhou, J., and Anderson, B.: Aircraft profiles of aerosol microphysics and optical properties over North America: Aerosol optical depth and its association with PM2.5 and water uptake, J. Geophys. Res., 112, D12S20, doi:10.1029/2006JD007918, 2007.

Smirnov, A., Holben, B. N., Giles, D. M., Slutsker, I., O’Neill, N. T., Eck, T. F., Macke, A., Croot, P., Courcoux, Y., Sakerin, S. M., Smyth, T. J., Zielinski, T., Zibordi, G., Goes, J. I., Harvey, M. J., Quinn, P. K., Nelson, N. B., Radionov, V. F., Duarte, C. M., Losno, R., Sciare, J., Voss, K. J., Kinne, S., Nalli, N. R., Joseph, E., Krishna Moorthy, K., Covert, D. S., Gulev, S. K., Milinevsky, G., Larouche, P., Belanger, S., Horne, E., Chin, M., Remer, L. A., Kahn, R. A., Reid, J. S., Schulz, M., Heald, C. L., Zhang, J., Lapina, K., Kleidman, R. G., Griesfeller, J., Gaitley, B. J., Tan, Q., and Diehl, T. L.: Maritime aerosol network as a component of AERONET - first results and comparison with global aerosol models and satellite retrievals, Atmos. Meas. Tech., 4, 583-597, doi:10.5194/amt-4-583-2011, 2011.

Thomas, G., Carboni, E., Sayer, A., Poulsen, C., Siddans, R., and Grainger, R.: Satellite aerosol remote sensing over land, chap. Oxford-RAL Aerosol and Cloud (ORAC): aerosol retrievals from satellite radiometers, 193-225, Springer-Praxis, 2009a.

Thomas, G. E., Poulsen, C. A., Sayer, A. M., Marsh, S. H., Dean, S. M., Carboni, E., Siddans, R., Grainger, R. G., and Lawrence, B. N.: The GRAPE aerosol retrieval algorithm, Atmos. Meas. Tech., 
2, 679-701, doi:10.5194/amt-2-679-2009, 2009b.

Thomas, G. E., Poulsen, C. A., Siddans, R., Sayer, A. M., Carboni, E., Marsh, S. H., Dean, S. M., Grainger, R. G., and Lawrence, B. N.: Validation of the GRAPE single view aerosol retrieval for ATSR-2 and insights into the long term global AOD trend over the ocean, Atmos. Chem. Phys., 10, 4849-4866, doi:10.5194/acp-10-4849-2010, 2010.

Turner, D. D., Ferrare, R. A., and Brasseur, L. A.: Average aerosol extinction and water vapour profiles over the Southern Great Plains, Geophys. Res. Lett., 28, 4441-4444, doi:10.1029/2001GL013691, 2001.

Weller, R. and Lampert, A.: Optical properties and sulfate scattering efficiency of boundary layer aerosol at coastal Neumayer Station, Antarctica, J. Geophys. Res., 113, D16208, doi:10.1029/2008JD009962, 2008.

Welton, E., Voss, K., Quinn, P., Flatau, P., Markowicz, K., Campbell, J., Spinhirne, J., Gordon, H., and Johnson, J.: Measurements of aerosol vertical profiles and optical properties during INDOEX 1999 using micropulse lidars, J. Geophys. Res, 107, 8019, doi:10.1029/2000JD000038, 2002.
Yu, H., Kaufman, Y. J., Chin, M., Feingold, G., Remer, L. A., Anderson, T. L., Balkanski, Y., Bellouin, N., Boucher, O., Christopher, S., DeCola, P., Kahn, R., Koch, D., Loeb, N., Reddy, M. S., Schulz, M., Takemura, T., and Zhou, M.: A review of measurement-based assessments of the aerosol direct radiative effect and forcing, Atmos. Chem. Phys., 6, 613-666, doi:10.5194/acp-6-613-2006, 2006.

Zhao, T.-P., Yu, H., Laszlo, I., Chin, M., and Conant, W.: Derivation of component aerosol direct radiative forcing at the top of atmosphere for clear-sky oceans, J. Quant. Spectrosc. Ra., 109, 1162-1186, 2008.

Zhao, T. X.-P., Loeb, N. G., Laszlo, I., and Zhou, M.: Global component aerosol direct radiative effect at the top of atmosphere, Int. J. Rem. Sens., 32, 633-655, doi:10.1080/01431161.2010.517790, 2011. 